\title{
Forkhead Box Protein O6
}

National Cancer Institute

\section{Source}

National Cancer Institute. Forkhead Box Protein O6. NCI Thesaurus. Code C101412.

Forkhead box protein $\mathrm{O} 6$ (492 aa, $\sim 51 \mathrm{kDa}$ ) is encoded by the human FOXO6 gene. This protein may play a role in the positive regulation of transcription. 